\title{
Late Quaternary palaeoenvironmental reconstruction from Lakes Ohrid and Prespa (Macedonia/Albania border) using stable isotopes
}

\author{
M. J. Leng ${ }^{1}$, I. Baneschi ${ }^{2}$, G. Zanchetta ${ }^{3,2,5}$, C. N. Jex ${ }^{1, *}$, B. Wagner ${ }^{4}$, and H. Vogel ${ }^{4}$ \\ ${ }^{1}$ NERC Isotope Geosciences Laboratory (NIGL), British Geological Survey, Nottingham, UK \\ ${ }^{2}$ Istituto di Geoscienze e Georisorse-CNR (IGG-CNR), Via Moruzzi, 156124 Pisa, Italy \\ ${ }^{3}$ Dipartimento di Scienze della Terra, University of Pisa, Via S. Maria, 53, 56126 Pisa, Italy \\ ${ }^{4}$ Institute for Geology and Mineralogy, University of Cologne, Köln, Germany \\ ${ }^{5}$ INGV sez. Pisa, Via della Faggiola, 32, 56124 Pisa, Italy \\ * current address: School of Geography, Earth and Environmental Sciences, The University of Birmingham, Birmingham, UK
}

Received: 4 May 2010 - Published in Biogeosciences Discuss.: 21 May 2010

Revised: 14 September 2010 - Accepted: 21 September 2010 - Published: 13 October 2010

\begin{abstract}
Here we present stable isotope data from three sediment records from lakes that lie along the MacedonianAlbanian border (Lake Prespa: 1 core, and Lake Ohrid: 2 cores). The records only overlap for the last $40 \mathrm{kyr}$, although the longest record contains the MIS 5/6 transition (Lake Ohrid). The sedimentary characteristics of both lakes differ significantly between the glacial and interglacial phases. At the end of MIS 6 Lake Ohrid's water level was low (high $\delta^{18} \mathrm{O}_{\text {calcite }}$ ) and, although productivity was increasing (high calcite content), the carbon supply was mainly from inorganic catchment rock sources (high $\delta^{13} \mathrm{C}_{\text {carb }}$ ). During the last interglacial, calcite and TOC production and preservation increased, progressively lower $\delta^{18} \mathrm{O}_{\text {calcite }}$ suggest increase in humidity and lake levels until around $115 \mathrm{ka}$. During ca. $80 \mathrm{ka}$ to $11 \mathrm{ka}$ the lake records suggest cold conditions as indicated by negligible calcite precipitation and low organic matter content. In Lake Ohrid, $\delta^{13} \mathrm{C}_{\text {org }}$ are complacent; in contrast, Lake Prespa shows consistently higher $\delta^{13} \mathrm{C}_{\text {org }}$ suggesting a low oxidation of ${ }^{13} \mathrm{C}$-depleted organic matter in agreement with a general deterioration of climate conditions during the glacial. From $15 \mathrm{ka}$ to the onset of the Holocene, calcite and TOC begin to increase, suggesting lake levels were probably low (high $\delta^{18} \mathrm{O}_{\text {calcite }}$ ). In the Holocene (11 ka to present) enhanced productivity is manifested by high calcite and organic matter content. All three cores show an early Holocene characterised by low $\delta^{18} \mathrm{O}_{\text {calcite, }}$, apart from the very early Holocene phase in Prespa where the lowest
\end{abstract}

Correspondence to: M. J. Leng (mjl@bgs.ac.uk) $\delta^{18} \mathrm{O}_{\text {calcite }}$ occurs at ca. $7.5 \mathrm{ka}$, suggesting a phase of higher lake level only in (the more sensitive) Lake Prespa. From $6 \mathrm{ka}, \delta^{18} \mathrm{O}_{\text {calcite }}$ suggest progressive aridification, in agreement with many other records in the Mediterranean, although the uppermost sediments in one core records low $\delta^{18} \mathrm{O}_{\text {calcite }}$ which we interpret as a result of human activity. Overall, the isotope data present here confirm that these two big lakes have captured the large scale, low frequency palaeoclimate variation that is seen in Mediterranean lakes, although in detail there is much palaeoclimate information that could be gained, especially small scale, high frequency differences between this region and the Mediterranean.

\section{Introduction}

The predictions of future climate suggest that changes in rainfall and water resources will have important socioeconomic and political impacts over the Mediterranean region (e.g. Bolle, 2003; Lionello et al., 2006). Therefore, understanding the past climatic and hydrological variability in this and surrounding areas is an essential prerequisite for establishing future climate scenarios and the possible impact on human society. Stable isotope data from lacustrine carbonates and organic matter are invaluable for defining regional climatic and hydrological changes (e.g. Leng and Marshall, 2004) and can be used to assess the spatial coherency of the climate and hydrological change across regions. Recently sixteen Mediterranean lacustrine carbonate stable isotope records have been used in a regional synthesis (Roberts et al., 2008) although this encompasses only one lake record

Published by Copernicus Publications on behalf of the European Geosciences Union. 


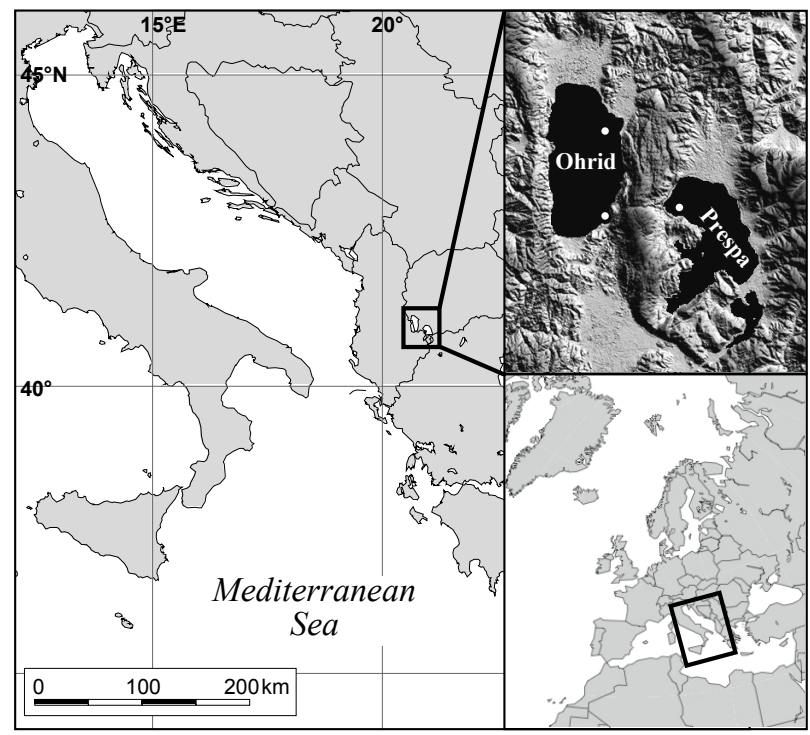

Fig. 1. Location of Lake Ohrid and Prespa including the coring locations (white spots). Mikri Prespa is to the SE of Lake Prespa. St. Naum spring is in the SE corner of Lake Ohrid.

from the Balkans (Frogley et al., 2001). Many of these Mediterranean records have been investigated at low resolution (e.g. Zanchetta et al., 1999; 2007a) and the correlation with other archives is hampered by the absence of a common robust chronology. Here, we discuss the stable isotope records of the two "sister" (hydrologically connected) lakes (Prespa and Ohrid) which are situated in the Balkans (Fig. 1). The stable isotope composition of lake sediment archives provides information on lake hydrology and climate (oxygen isotopes) and well as sources and productivity of the lake and it's catchments (carbon isotopes). Only one previous study has presented carbonate isotope data from Lake Ohrid (ostracod shells); these data agree with the broad palaeoenvironment reconstruction from other proxy data since $140 \mathrm{ka}$ (Lezine et al., 2010). Significant differences in the two lakes in terms of size, bathymetry, and subsequent lake water residence time make these two lakes potentially able to supply complementary hydrological records through the late Quaternary.

\section{General setting}

Lake Prespa and Lake Ohrid are situated in south-eastern Europe between Albania, Macedonia and Greece (Fig. 1), they are hydraulically connected by a karst system within the Mali Thate (2287 meters above sea level (m.a.s.l.)) and Galicica (2262 ma.s.1.) mountains, which represents the local topographic divide between the two lakes. Structurally, both lakes are developed in tectonic grabens, formed during the latter phases of the Alpine Orogeny in the Pliocene (Aliaj et al.,
Table 1. Characteristics of Lake Prespa and Lake Ohrid (data after Matzinger et al., 2006a).

\begin{tabular}{lll}
\hline Property & Prespa & Ohrid \\
\hline Altitude (ma.s.l) & 849 & 693 \\
Catchment area $\left(\mathrm{km}^{2}\right)$ & 1300 & $2610^{*}$ \\
Surface area $\left(\mathrm{km}^{2}\right)$ & 254 & 358 \\
Max. depth $(\mathrm{m})$ & 48 & 286 \\
Volume $\left(\mathrm{km}^{3}\right)$ & 3.6 & 55.4 \\
Hydraulic residence time $(\mathrm{yr})$ & 11 & 70 \\
\hline
\end{tabular}

*including Lake Prespa and its catchment.

2001). Owing to the lakes' position within the rain shadow of the surrounding mountain ranges, and the proximity to the Adriatic Sea, both lake catchments are under the influence of the Mediterranean climate with a more limited influence of a continental climate (Watzin et al., 2002).

Lake Prespa is located at $849 \mathrm{~m}$ a.s.l. (ca. $150 \mathrm{~m}$ above Lake Ohrid) and has a volume of ca. $3.6 \mathrm{~km}^{3}$ (Table 1). To the south, Lake Prespa is connected to a smaller lake, called Mikri Prespa, by a controllable man-made channel with a current hydraulic head of $3 \mathrm{~m}$ (Hollis and Stevenson, 1997). The total inflow into Lake Prespa is estimated to be $16.9 \mathrm{~m}^{3} \mathrm{~s}^{-1}$, with $56 \%$ originating from river runoff from numerous small streams, 35\% from direct precipitation, and 9\% from Mikri Prespa to the south (Matzinger et al., 2006b). Lake Prespa has no surface outlet. Water loss is through evaporation (52\%), irrigation (2\%) and outflow through the karst aquifer (46\%); the latter leading to springs, some of which flow into Lake Ohrid (Matzinger et al., 2006b). The hydraulic residence time in Lake Prespa is estimated to be ca. $11 \mathrm{yr}$. A significant lake level decrease of more than $7 \mathrm{~m}$ was measured between 1965 and 1996 (Popovska and Bonacci, 2007), and an additional lowering of at least $1 \mathrm{~m}$ was observed during the past 9 years, meaning that the lakewater is particularly responsive to climate variation and water exploitation for human uses. As Lake Prespa is relatively shallow with respect to the large surface area, windinduced mixis leads to a complete destratification of the water column from autumn to spring (Matzinger et al., 2006b). Anoxic bottom waters in summer and an average concentration of $31 \mathrm{mg} \mathrm{m}^{-3}$ total phosphorus (TP) in the water column, characterize the lake as mesotrophic today. However, sediment cores and hydrological measurements indicate recent eutrophication (Matzinger et al., 2006b) and imply that Lake Prespa was more oligotrophic in the past (Wagner et al., 2010).

Lake Ohrid is located at an altitude of $693 \mathrm{~m}$ a.s.l. and has a lake water volume of about $55.4 \mathrm{~km}^{3}$ (Table 1). Bathymetric measurements revealed that the basin occupied by the lake has a simple morphology with a maximum water depth of $289 \mathrm{~m}$. A complete overturn of the entire water column 
occurs approximately once every 7 years, whereas the upper $200 \mathrm{~m}$ of the water column is mixed every winter (Hadzisce, 1966; Matzinger et al., 2007). Matzinger et al. (2006a) calculated a theoretical hydraulic water residence time of ca. 70 years. Hydrologically, ca. 50\% of the inflow is from karst aquifers and minor contribution from rivers and direct precipitation (Matzinger et al., 2006a). Today, river runoff contributes ca. $20 \%$ to the total inflow which includes inflow from the River Sateska which was diverted into the northern part of Lake Ohrid in 1962. About $50 \%$ of aquifer input is thought to enter the lake as sublacustrine flow, and $50 \%$ as surface inflow, which is concentrated at the southeastern and northwestern edge of the lake (cf. Matter et al., 2010). The karst aquifers are charged by precipitation and by springs emanating from (the topographically higher) Lake Prespa (Stankovic, 1960; Anovski et al., 1980; Matzinger et al., 2006a; Amataj et al., 2007). The outflow of Lake Ohrid is the river Crni Drim in the northern part of the lake, which accounts for $63 \%$ of the water loss, with the remaining $37 \%$ accounted for by evaporation (Watzin et al., 2002).

\section{Material and methods}

Sediment cores retrieved from both lakes were obtained using a floating platform, gravity and piston corers (UWITEC Corp. Austria). The coring sites were chosen on the basis of locating undisturbed sediment via hydroacoustic surveys. Core composite records were obtained by correlation of individual $3 \mathrm{~m}$ long core sections using a variety of methods including visual inspection of the sediment composition, as well as aligning optical, magnetic and geochemical marker horizons (Wagner et al., 2008, 2010; Vogel et al., 2010a; 2010b). The longest (composite record of $14.94 \mathrm{~m}$ ) and best dated sediment record from Lake Ohrid is core Co1202 recovered from the northeastern part of the lake in autumn 2007 (Vogel et al., 2010a; 2010b, Fig. 1) from $145 \mathrm{~m}$ water depth. A $10.75 \mathrm{~m}$ core, Lz1120, was recovered in the summer 2003 in the south-eastern part of the lake basin (Fig. 1), from a water depth of $105 \mathrm{~m}$ (Wagner et al., 2008; 2009). From Lake Prespa, a $10.5 \mathrm{~m}$ long sediment sequence was recovered in autumn 2007 (core Co1204). The Co1204 coring location was in the northwestern part of the lake (Fig. 1), in a water depth of $14 \mathrm{~m}$. Detailed core descriptions, chronology and geochemical measurement (except stable isotopes) are discussed by Wagner et al. $(2008,2009,2010)$ and Vogel et al. (2010a, b). Here we present stable isotope data from the modern waters as well as carbonate oxygen and carbon isotopes, organic carbon isotopes supported by carbon and nitrogen content data. We show these new data alongside previously published total organic carbon (TOC) and calcite $\left(\mathrm{CaCO}_{3}\right)$ content.

\subsection{Oxygen and hydrogen isotope analysis of modern lake waters}

Water isotope data include data from a monitoring period between 1984-2000 published by Anovski et al. (1991) and Anovski (2000) and data from waters reported in Matzinger et al. (2006a), as well as new data from samples collected between August 2008-October 2009 and analysed as part of this study (from both IGG and NIGL, see author's addresses). At IGG the oxygen isotopic composition was determined by the water- $\mathrm{CO}_{2}$ equilibration method at $25^{\circ} \mathrm{C}$ with mass spectrometry using a SerCon GEO 20-20. For hydrogen isotope analysis, waters were reduced to $\mathrm{H}_{2}$ at $460^{\circ} \mathrm{C}$ using $\mathrm{Zn}$ and mass spectrometry using a ThermoFinnigam DELTA XP. At NIGL the waters were equilibrated with $\mathrm{CO}_{2}$ using an Isoprep 18 device for oxygen isotope analysis with mass spectrometry using a VG SIRA. For hydrogen isotope analysis, an on-line $\mathrm{Cr}$ reduction method was used with a EuroPyrOH3110 system coupled to a Micromass Isoprime mass spectrometer. Isotopic ratios $\left({ }^{18} \mathrm{O} /{ }^{16} \mathrm{O}\right.$ and $\left.{ }^{2} \mathrm{H} /{ }^{1} \mathrm{H}\right)$ are expressed in delta units, $\delta^{18} \mathrm{O}$ and $\delta \mathrm{D}$ (\%o, parts per mille), and defined in relation to the international standard, VSMOW (Vienna Standard Mean Ocean Water). Analytical precision is typically $<0.2 \%$ of $\delta^{18} \mathrm{O}$ and $\pm 1.0 \%$ for $\delta \mathrm{D}$.

\subsection{Carbonate and organic matter stable isotope analysis}

The stable isotope analysis of the core sediments from both Lake Prespa and Lake Ohrid were undertaken at both IGG (Prespa, Co1204) and NIGL (Ohrid, Co1202 and Lz1120). Both laboratories employ similar methods for both carbonate $\delta^{18} \mathrm{O}$ and $\delta^{13} \mathrm{C}$ and organic matter $\delta^{13} \mathrm{C}$. The details are given below:

\subsubsection{Carbonate analysis}

The core from Lake Prespa (Co1204) was sampled for oxygen and carbon isotopes on bulk carbonate at $5 \mathrm{~cm}$ intervals down ca. to $285 \mathrm{~cm}$. Thereafter, the carbonate content decreases to only trace amounts. The samples were dried at $40^{\circ} \mathrm{C}$ and powdered. Sub-samples of the powder for bulk carbonate $\delta^{18} \mathrm{O}$ and $\delta^{13} \mathrm{C}$ were analysed with no further pretreatment. $\mathrm{CO}_{2}$ was evolved by reaction with $100 \%$ phosphoric acid at $70^{\circ} \mathrm{C}$ for $1 \mathrm{~h}$ under vacuum; the $\mathrm{CO}_{2}$ was cryogenically separated from water vapour under vacuum and collected for analysis using a Varian Mat 252 mass spectrometer.

The cores from Lake Ohrid (Co1202 and Lz1120) were sampled for oxygen and carbon isotopes on carbonate at $8 \mathrm{~cm}$ and $4 \mathrm{~cm}$ intervals down to approximately the base of each core (but with very low carbonate concentrations in the glacial, most of these samples failed to run). The samples were gently disaggregated in 5\% sodium hypochlorite solution for $24 \mathrm{~h}$ to oxidise reactive organic material. Samples 
were then washed three times in distilled water and sieved at $85 \mu \mathrm{m}$ to remove any shelly fragments. The $<85 \mu \mathrm{m}$ fraction was filtered, washed with deionised water and dried at $40^{\circ} \mathrm{C}$ and ground in agate. $\mathrm{CO}_{2}$ was evolved by reaction with anhydrous phosphoric acid within a vacuum overnight at a constant $25^{\circ} \mathrm{C}$. The $\mathrm{CO}_{2}$ was cryogenically separated from water vapour under vacuum and collected for analysis using a VG Optima dual inlet mass spectrometer.

Carbon and oxygen isotope values $\left(\delta^{13} \mathrm{C}_{\text {calcite }}, \delta^{18} \mathrm{O}_{\text {calcite }}\right)$ from both laboratories are reported as per mille (\%o) deviations of the isotopic ratios $\left({ }^{13} \mathrm{C} /{ }^{12} \mathrm{C},{ }^{18} \mathrm{O} /{ }^{16} \mathrm{O}\right)$ calculated to the VPDB scale using within-run laboratory standards (MS, MAB and MOM at IGG and MCS at NIGL) and international standards NBS18, NBS19 and NBS 22. Overall analytical reproducibility for these samples was $<0.1 \%$ for $\delta^{13} \mathrm{C}$ and $\delta^{18} \mathrm{O}$.

\subsubsection{Organic analysis}

The core from Lake Prespa (Co1204) was sampled for organic carbon isotopes at $10 \mathrm{~cm}$ through the whole core (down to $10.5 \mathrm{~m}$ ). The samples were dried at $40^{\circ} \mathrm{C}$ and powdered. The powders were treated with $10 \% \mathrm{HCl}$ to remove carbonate, washed several times with distilled water to neutral $\mathrm{pH}$, and then dried again at $40^{\circ} \mathrm{C} . \mathrm{CO}_{2}$ was evolved by combustion using a Carlo Erba 1108 elemental analyser, interfaced to a Finnigan DeltaPlusXL via the Finnigan MAT Conflo II interface. Concentrations of total carbon (TC) and total nitrogen (TN) were measured with a MICRO CUBE elemental analyzer (VARIO Co.). Total organic carbon (TOC) was quantified from the difference between total carbon (TC) and total inorganic carbon (TIC), which were measured with a DIMATOC 200 (DIMATEC Coop.). These measurements were also used to calculate the $\mathrm{C} / \mathrm{N}$ ratio.

The cores from Lake Ohrid (Co1202 and Lz1120) were sampled for organic carbon isotopes at $8 \mathrm{~cm}$ and $4 \mathrm{~cm}$ intervals to the base of each core (but with quite a lot of samples that were unable to be measured because of the low abundance of organic matter in the glacial period especially in Lz1120).

The samples were treated with $5 \% \mathrm{HCl}$ to remove carbonate, washed several times with distilled water to neutral $\mathrm{pH}$, and then dried again at $40^{\circ} \mathrm{C}$. $\mathrm{CO}_{2}$ was evolved by combustion using a Costech Elemental Analyser (EA) on-line to a VG TripleTrap and Optima dual-inlet mass spectrometer. At NIGL \% total organic carbon $(\% \mathrm{C})$ and $\%$ total nitrogen $(\% \mathrm{~N})$ were measured at the same time at the isotope measurements and thus $\mathrm{C} / \mathrm{N}$ was calculated, calibrated against an Acetanilide standard (precision generally $<0.1$ ).

Organic carbon isotope values $\left(\delta^{13} \mathrm{C}_{\mathrm{org}}\right)$ from both laboratories are reported as per mille (\%o) deviations of the isotopic ratios $\left({ }^{13} \mathrm{C} /{ }^{12} \mathrm{C}\right)$ calculated to the VPDB scale using a withinrun laboratory standards (graphite and ANU-sucrose at IGG and BROC at NIGL) and international standards NBS18,
NBS19 and NBS 22. Overall analytical reproducibility for these samples was $<0.1 \%$ ofor $\delta^{13} \mathrm{C}$.

\section{Chronology}

The chronology of the cores from Lakes Prespa and Ohrid are based on radiocarbon dating, supported by the presence of precisely identified tephra layers with a relatively well constrained age, which also allow the physical links of the two records (Sulpizio et al., 2010; Wagner et al., 2010). Radiocarbon dating was performed principally on macrofossil remains using accelerator mass spectrometry (AMS) at the Leibniz Laboratory for Radiometric Dating and Isotope Research in Kiel, Germany. Reliable radiocarbon ages were calibrated into calendar years before present (cal yrs BP) using CalPal-2007 ${ }^{\text {online }}$ and the Cal-Pal2007_HULU calibration curve (Danzeglocke et al., 2009). Wagner et al. (2008), Sulpizio et al. (2010), and Vogel et al. (2010a) discuss the tephra layers and their chronology. Three tephra layers are common in cores Co1204 and Co1202 records during the Late Pleistocene: the Y5 (ca. $40 \mathrm{ka}$ ), Codola (ca. $33 \mathrm{ka}$ ) and the Y3 (ca. $30 \mathrm{ka}$ ), whereas core Lz1120 shares with Co1202 the tephra FL (ca. 3300 cal yr BP), Y5 and Y3; and Co1204 with tephra Y5 and Y3. The age-depth model for these cores is based on the assumption that the sediment surface represents the year of the coring campaign (2005 for Lz1120 and 2007 for Co1202 and Co1204) and on a linear interpolation between the dated layers after removal of the tephra thickness (Wagner et al., 2008, 2010; Vogel et al., 2010a). Based on the tephra horizons and the results of the radiocarbon dating, it can be assumed that the record from Lake Prespa covers continuously the past ca. $48 \mathrm{ka}$, whereas the record of Co1202 covers ca. the last $136 \mathrm{ka}$, and Lz1120 covers $40 \mathrm{ka}$. Significant hiatuses have been found to occur within the Lake Ohrid cores, in Lz1120 a hiatus of almost $5 \mathrm{kyr}$ occurs between the Holocene and Late Glacial transition (ca. 15-10 ka) (Wagner et al., 2008), while in Co1202 a hiatus of almost $16 \mathrm{kyr}$ occurs within MIS5 (ca. 100-80 ka) prior to the onset of MIS4 (Vogel et al., 2010a).

\section{Results}

\subsection{Modern waters}

The isotopic composition of present day waters from springs around lakes Ohrid and Prespa (and Mikri Prespa), as well as the lakes themselves, are given in Fig. 2. The isotopic composition of the present day lake waters fall on a local evaporation line (LEL) away from the global meteoric water line (GMWL) between -10.2 and $+1.2 \%$ of $\delta^{18} \mathrm{O}$ and $-69.9 \%$ and $-12.9 \%$ or $\delta \mathrm{D}$. Anovsky et al. (1991) and Eftimi and Zoto (1997) report a local meteoric water line that was characterised by a deuterium excess of ca. 14\%, suggesting a 


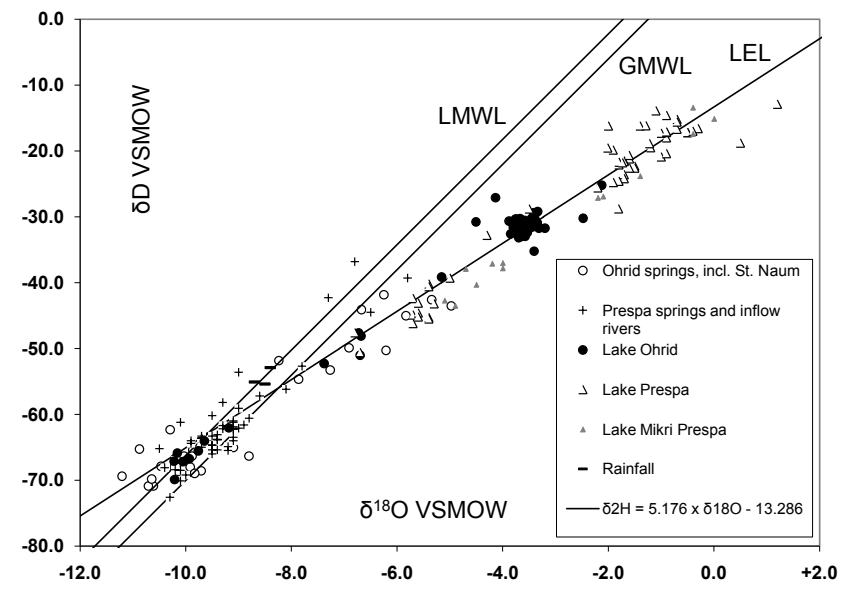

Fig. 2. The isotopic $\left(\delta^{18} \mathrm{O}\right.$ and $\left.\delta \mathrm{D}\right)$ composition of present day waters from a variety of springs around Lakes Ohrid and Prespa (and Lake Mikri Prespa), as well as the lakes themselves. The Global Meteoric Water Line (GMWL) and the Local Meteoric Water Line (LMWL, Anovsky et al., 1991; and Eftimi and Zoto, 1997) are also given.

component of meteoric water evaporated from the Mediterranean (e.g. Gat et al., 2003; Dotsika et al., 2010). Both lakes are evaporated and the intersection of the LEL with the GMWL at around $\delta^{18} \mathrm{O}=-8.8 \%$ and $\delta \mathrm{D}=-56.2 \%$ suggests that both lakes are recharged from groundwater falling about in the midpoint of the range of springs in the region $\left(\delta^{18} \mathrm{O}\right.$ springs range from $-4.9 \%$ to $-11.2 \%$ ). This range in spring waters that enter both Lake Ohrid and Prespa suggests that while there is obviously a large component of ground water (mean weighted $\delta^{18} \mathrm{O}$ measure in precipitation close to the lakes ranges from $-8.5 \%$ to $-8.4 \%$ e.g. Anovski, 2000) many of the springs are from seasonal rainfall, and are most likely supplied by isotopically depleted winter rainfall given the seasonal distribution of rainfall to this region.

The majority of the lake water samples from Lake Ohrid have $\delta^{18} \mathrm{O}$ and $\delta \mathrm{D}$ values that are very stable around $-4 \%$ o and $-32 \%$ o respectively, although there are a few scattered samples (mostly from the lake water collection period in 2001 and 2002 of Matzinger et al., 2006b) which have a wider range in isotope composition. Some of Lake Ohrid's waters plot on or closer to the GMWL showing that these samples were collected close to subaqueous spring waters entering the lake. Lake Prespa $\delta^{18} \mathrm{O}$ and $\delta \mathrm{D}$ in contrast are highly variable. Lake Prespa and Mikri Prespa have an almost identical range in isotope composition with $\delta^{18} \mathrm{O}$ from ca. -7 to $0 \%$. The two Prespa lakes are clearly very sensitive to moisture balance in the region and respond dramatically to seasonality, both becoming more evaporated in the summer months and fresher during winter recharge (cf., Popovska and Bonacci, 2007), probably due to the dominance of shallow groundwater. This difference in the isotope composition of Ohrid and Prespa water is probably a function of their lake to volume/surface ratios, being higher in Lake Ohrid

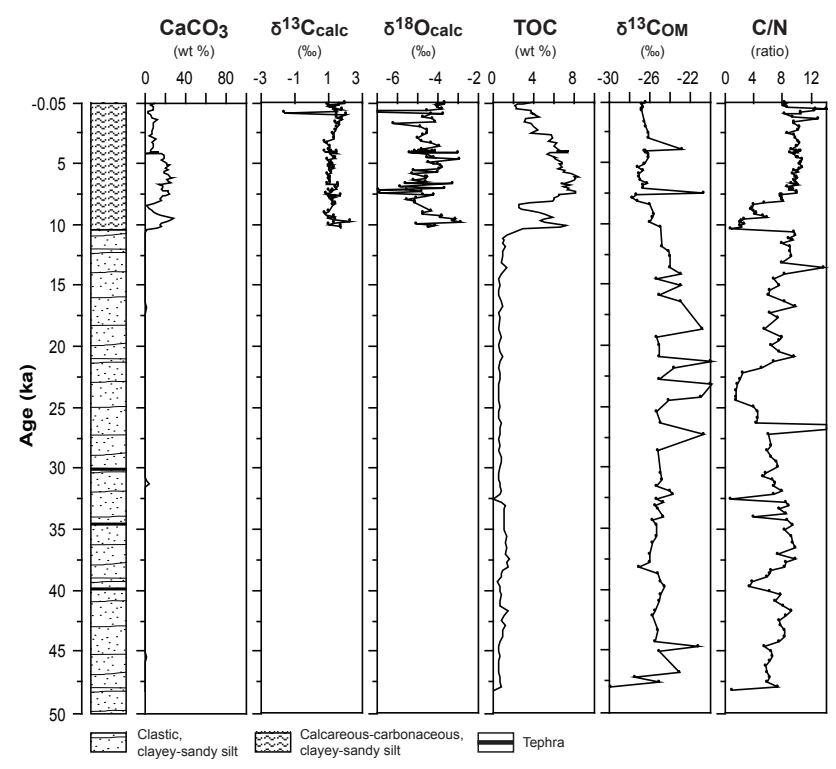

Fig. 3. Calcite and organic matter concentration and isotope data from Lake Prespa core Co1204.

than Lake Prespa (0.15 and 0.014 respectively, Matzinger et al., 2006a), which also leads to significantly different lake water residence times in the two lakes (ca. $70 \mathrm{yr}$ for Ohrid and ca. $11 \mathrm{yr}$ for Prespa, Table 1). Previous stable isotope and tracer experiments have shown that water from Lake Prespa is flowing into Lake Ohrid through karst channels (Matzinger et al., 2006b), so effectively Prespa is contributing water that sits closer to the GMWL in the winter months and enriched water in the summer months. Stable isotopes and $\mathrm{Cl}^{-}$established that the spring water at St. Naum (located in the SE corner of lake Ohrid) is fed by $43 \pm 5 \%$ from Lake Prespa (evaporated water) and $57 \pm 5 \%$ from local precipitation (local recharge which may vary on a seasonal basis). The consistent nature of Lake Ohrid water (while Lake Prespa varies in $\delta^{18} \mathrm{O}$ by $6 \%$ ) however suggests that the input of evaporated lake water from Prespa has a minimal effect on Lake Ohrid overall, and that the lake has reached steady state at least over the sampling period of the modern lakewaters (i.e. 20-30 years) with little variability from the mean apart from around the margins where spring water enters the lake. In terms of understanding past lake water balance from the oxygen isotope composition of lacustrine carbonate $\delta^{18} \mathrm{O}$ composition, we would interpret $\delta^{18} \mathrm{O}$ variation in Lake Ohrid to represent low frequency climate variation while Lake Prespa will be much more responsive to higher frequency variation and should show a larger magnitude of variation depending on the sampling resolution. Both lakes, however, should respond to the same water balance forcing overall. 


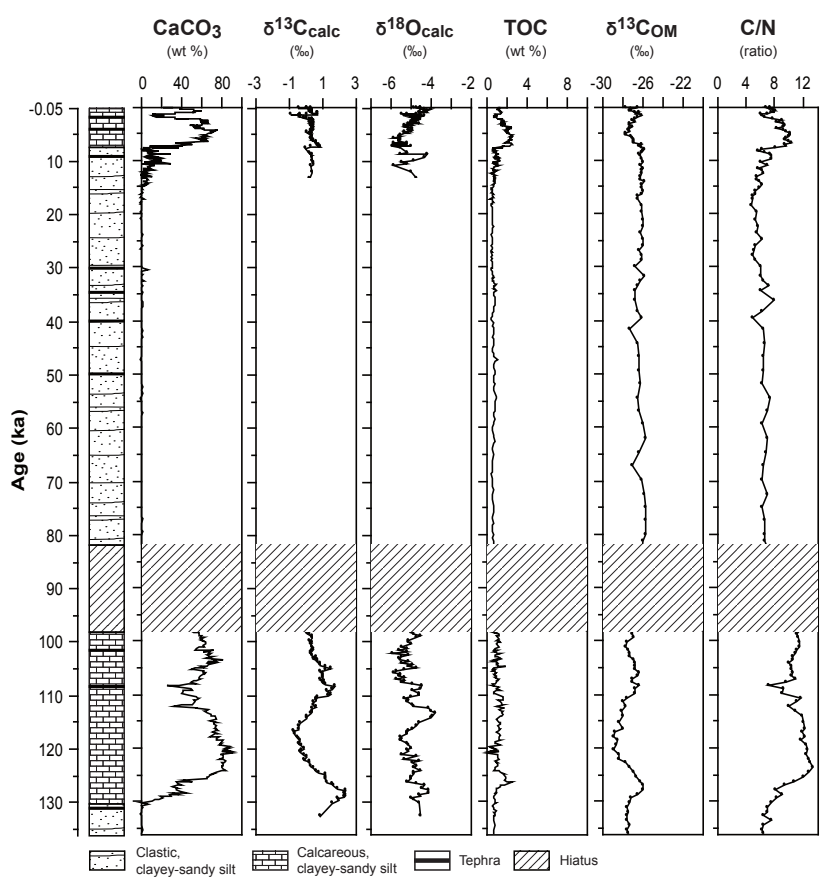

Fig. 4. Calcite and organic matter concentration and isotope data from Lake Ohrid core Co1202.

\subsection{Prespa sediment archive}

Prespa core Co1204 covers the period from ca. $48 \mathrm{ka}$ to the present (Wagner et al., 2010). From the base to $10 \mathrm{ka}$ (MIS 3 and 2) calcite content is negligible and TOC is mostly $<1 \%$ (Fig. 3). Calcite content increases in the core (reaching $30 \%$, significantly lower than the Lake Ohrid cores, Figs. 4 and 5) after $10 \mathrm{ka}$, with a decrease after about $5 \mathrm{ka}$ to values around $5-10 \%$ in the top of the core. In the Holocene, TOC increases to values between $2-8 \%$, significantly higher than this period in the Lake Ohrid cores. Calcite oxygen and carbon isotope ratios were only measured in the Holocene section because calcite is negligible in the glacial section. Organic carbon isotopes were measured through the whole core. Through the last $10 \mathrm{ka}$ of the core $\delta^{18} \mathrm{O}_{\text {calcite values }}$ fluctuate between ca. $-8 \%$ o to $-3 \%$, there is a decrease from $10 \mathrm{ka}$ to $7.5 \mathrm{ka}$, thereafter the values rise; this rise coincides with a decrease in calcite and TOC content. $\delta^{13} \mathrm{C}_{\text {calcite }}$ values fluctuate around 0 and $+2 \%$ although there is a slight increase towards the late Holocene, and a high value towards the top. There is no correlation between $\delta^{18} \mathrm{O}_{\text {calcite }}$ and $\delta^{13} \mathrm{C}_{\text {calcite }}\left(\mathrm{r}^{2}=0.05\right) . \delta^{13} \mathrm{C}_{\text {org }}$ variation is fairly uniform being around $-25 \%$ in the glacial to ca. $-27 \%$ in the Holocene with noticeable spikes to higher values. $\mathrm{C} / \mathrm{N}$ values fluctuate over the whole core between 2 and 13, being generally higher in the Holocene.

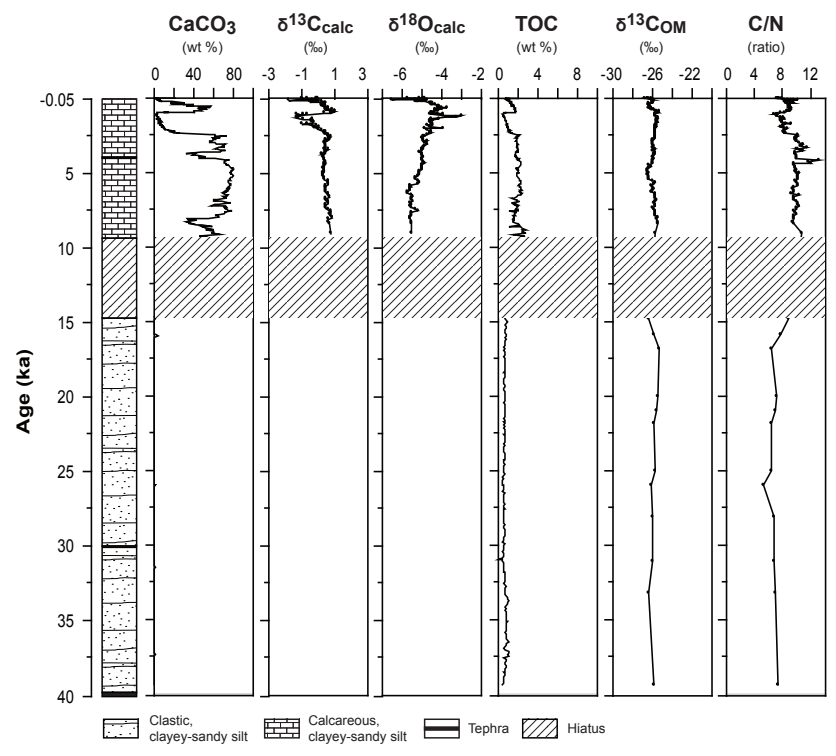

Fig. 5. Calcite and organic matter concentration and isotope data from Lake Ohrid core Lz1120.

\subsection{Ohrid sediment archives}

Ohrid core Co1202 covers the period from ca. $136 \mathrm{ka}$ to present, with a hiatus between ca. 97.6 and $81.7 \mathrm{ka}$ (Vogel et al., 20010a). Calcite is abundant in the core from 130 to ca. $98 \mathrm{ka}$, it is low between 82 and $15 \mathrm{ka}$, but increases sharply again after $7 \mathrm{ka}$. Organic carbon fluctuates between 0.5 and $2.5 \%$, with higher content occurring in the parts with high concentrations of calcite (Fig. 4). Calcite oxygen and carbon isotope ratios were only measured in the interglacials (the end of MIS 6, 5 and 1), within the last glacial (MIS 4, 3,2 ) calcite content is negligible (Fig. 4). Organic carbon isotopes were measured in the same periods as the calcite isotopes and also at lower temporal resolution through the cold glacial period. From the base of the core to ca. $98 \mathrm{ka}$ $\delta^{18} \mathrm{O}_{\text {calcite }}$ values fluctuate between $-6.0 \%$ o to $-3.8 \%$, the decrease from the base to $118 \mathrm{ka}$ coincides with an increase in calcite content at the MIS6 to 5 transition. $\delta^{18} \mathrm{O}_{\text {calcite }}$ peaks at $114 \mathrm{ka}$ before declining. $\delta^{13} \mathrm{C}_{\text {calcite }}$ values are broadly similar, fluctuating between -1.0 and $+2.5 \%$. $\delta^{18} \mathrm{O}_{\text {calcite }}$ and $\delta^{13} \mathrm{C}_{\text {calcite }}$ appear in antiphase with calcite content. Organic

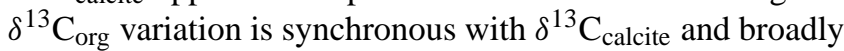
in antiphase with $\mathrm{C} / \mathrm{N}$. After $15 \mathrm{ka}$ calcite and organic content rise from very low content in the glacial period. Peak values begin at ca. $7 \mathrm{ka}$. Through this period $\delta^{18} \mathrm{O}_{\text {calcite }}$ steadily rise while $\delta^{13} \mathrm{C}_{\text {calcite }}$ values are stable around $+0.5 \%$. The antiphase relationship between $\delta^{13} \mathrm{C}_{\text {org }}$ and $\mathrm{C} / \mathrm{N}$ is retained, broadly following calcite and TOC concentrations.

Ohrid core Lz1120 covers the period from ca. $40 \mathrm{ka}$ to present, with a hiatus between ca. 14.5 and $9.4 \mathrm{ka}$ (Wagner et al., 2008). From the base to $14.5 \mathrm{ka}$ (MIS 3 and 2) calcite content is negligible and TOC is mostly $<1 \%$ (Fig. 5). 
Calcite is abundant (reaching $80 \%$ ) in the core after $9.4 \mathrm{ka}$, with a decrease between 2.4 to $1 \mathrm{ka}$ as in Co1202. Organic carbon fluctuates between 1 and $2.5 \%$ and, as with Co1202 broadly corresponds with calcite concentrations. Organic carbon isotopes were measured through the whole sequence but at lower temporal resolution through the $>14.5 \mathrm{ka}$ period. In the Holocene (from $9.4 \mathrm{ka}$ ) $\delta^{18} \mathrm{O}_{\text {calcite }}$ values fluctuate between $-6.0 \%$ to $-3 \%$, a similar range to values

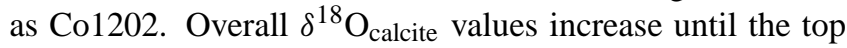
of the core when then return to lower values. As with the Holocene calcite in $\mathrm{Co} 1202, \delta^{18} \mathrm{O}_{\text {calcite }}$ values peak in the late Holocene. $\delta^{13} \mathrm{C}_{\text {calcite }}$ values are broadly similar fluctuating between -2.0 and $+1 \%$, although the trough in Co1202 is more evident in Lz1120 at around $0.5 \mathrm{ka} . \delta^{18} \mathrm{O}_{\text {calcite }}$ and $\delta^{13} \mathrm{C}_{\text {calcite }}$ appear in antiphase with calcite content although this relationship is much more ambiguous in this core. Organic $\delta^{13} \mathrm{C}_{\text {org }}$ variation is less synchronous with $\delta^{13} \mathrm{C}_{\text {calcite }}$ although the $\delta^{13} \mathrm{C}_{\text {calcite }}$ low at around $0.5 \mathrm{ka}$ matches with the $\delta^{13} \mathrm{C}_{\text {org }}$ high, which also is the period of low $\mathrm{C} / \mathrm{N}$.

\section{Discussion}

\subsection{Oxygen isotope composition of bulk calcite}

The modern water isotope $\left(\delta^{18} \mathrm{O}_{\text {lakewater }}\right.$ and $\delta \mathrm{D}_{\text {lakewater }}$, Fig. 2) composition of Lake Prespa shows high variability related to the amount of rainfall (which is also reflected in the variability in lake level of Lake Prespa (Anovski, 2001)) and evaporation (the input/evaporation ratio $\mathrm{I} / \mathrm{E}$ ). This effect is not significant in Ohrid (at least over the last 20-30 years) probably because the higher volume/surface ratio of the lake, making it less sensitive to variations in moisture balance. The longer residence time of lake water in Ohrid and the higher lakewater volume means that Ohrid has likely reached steady state and changes in lake water isotope composition are forced by low frequency climate variation. The oxygen isotope composition of the lakewater in Prespa and Ohrid is captured in authigenic (endogenic) calcite precipitated in the lakes. The mechanism for the calcite precipitation is thought to occur during the spring-summer in the epilimnion, when photoautotropic organisms assimilate $\mathrm{CO}_{2}$ (Wetzel, 2001) as long as there is a supply of $\mathrm{Ca}$ and bicarbonate. $\mathrm{Ca}^{2+}$ and $\mathrm{HCO}_{3}^{-}$are thought to be derived mainly from the karstic springs (Matzinger et al., 2006b), while surface run-off into the lake and direct precipitation will dilute the lakewaters. This is counter balanced by evaporation and dissolution of calcite in the water column triggered by aerobic decomposition of organic matter (Vogel et al., 2010b). Production of authigenic calcite is common in mid-latitude lakes (Leng and Marshall, 2004) and across the Mediterranean region especially those on karst catchments (Roberts et al., 2008). Wagner et al. (2010) show increases of both calcite and organic matter during interglacials (both lakes) and suggest that these corresponding increases are due to a rise in primary productivity as a result of the transition from cold glacial to warmer interstadial climate conditions (i.e. around $130 \mathrm{ka}$ to $98 \mathrm{ka}$ and during the last $15 \mathrm{ka}$ ).

If we interpret the variability in $\delta^{18} \mathrm{O}_{\text {calcite }}$ in both lakes as archives of hydrological balance (i.e. I/E) captured through the $\delta^{18} \mathrm{O}$ of the lakewaters and subsequently incorporated into the authigenic calcites precipitated in the surface waters of the lakes, then changes in these parameters should be synchronous within and between the two lakes. However given the difference in Prespa and Ohrid lakewater $\delta^{18} \mathrm{O}$ variation, we would expect that the record captured in calcite $\delta^{18} \mathrm{O}_{\text {calcite }}$ should be similar although significantly damped in the Ohrid sediments. Changes in $\delta^{18} \mathrm{O}_{\text {calcite }}$ from Ohrid are therefore more likely to represent lower frequency variation. In general then, higher $\delta^{18} \mathrm{O}_{\text {calcite }}$ values are indicative of phases of reduced $\mathrm{I} / \mathrm{E}$ while lower $\delta^{18} \mathrm{O}_{\text {calcite values }}$ are more consistent with greater I/E. This also implies that variations in $\delta^{18} \mathrm{O}_{\text {calcite }}$ may represent variation in lake level, even if this is not necessarily the case. However, we also acknowledge that authigenic calcites will integrate climate signals within the sample size selected. For core Co1202 sedimentation rates vary between $0.05 \mathrm{~cm} / \mathrm{yr}$ (late Holocene) and $0.01 \mathrm{~cm} / \mathrm{yr}$ (Last Glacial), for core Lz1120 the sedimentation rate varies between $0.06 \mathrm{~cm} / \mathrm{yr}$ (Holocene) and $0.02 \mathrm{~cm} / \mathrm{yr}$ (Last Glacial), whereas for core Co1204 the sedimentation rate varies between $0.03 \mathrm{~cm} / \mathrm{yr}$ (Holocene) and $0.02 \mathrm{~cm} / \mathrm{yr}$ (Last Glacial). This implies that samples contain an average signal of between ca. 20 to 200 years (for samples thicknesses of $2 \mathrm{~cm}$ ) and that Holocene sedimentation is always greater than the Last Glacial so more of the signal is likely to be captured (i.e. high frequency variation).

Deviation of this general simple model of $\delta^{18} \mathrm{O}_{\text {calcite }}$ being directly a measure of $\mathrm{I} / \mathrm{E}$ can arise due to a variety of other factors, for instance, during phases with a significant proportion of clastic material entering the lake, there may be a component of detrital carbonate grains, especially in karstic catchments. Detrital carbonates often have different isotope compositions when compared to authigenic calcites in the sample sediments (e.g. Leng et al., 2010) although this is not always the case. Around Lake Ohrid we sampled the local catchment limestones and they have variable $\delta^{18} \mathrm{O}_{\text {carb }}$ values between $-9.7 \%$ and $-2.6 \%$ (Fig. 6), some of which are within the range of the authigenic carbonates from the lake, although we don't see the very low values around $-8 \%$ o to $-9 \%$, and no obvious mixing trend towards these values (Fig. 6). It would be difficult on an isotope basis to unravel authigenic from detrital as during wetter (more freshwater) periods the lakewater would become fresher (lower $\delta^{18} \mathrm{O}_{\text {lakewater }}$ at the same time as potentially more detrital carbonates with $\delta^{18} \mathrm{O}_{\text {carb }}$ going down to $-9.7 \%$ ). SEM investigation of the calcite from the Lake Ohrid sediments show ca. $<30 \mu \mathrm{m}$ idiomorphic calcite crystals (Fig. 4 in Matter et al., 2010) that are typical of authigenic precipitation (Leng et al., 2010). This is in agreement with similar findings of Belmecheri et al. (2009) and Lézine et al. (2010) in the lake. 


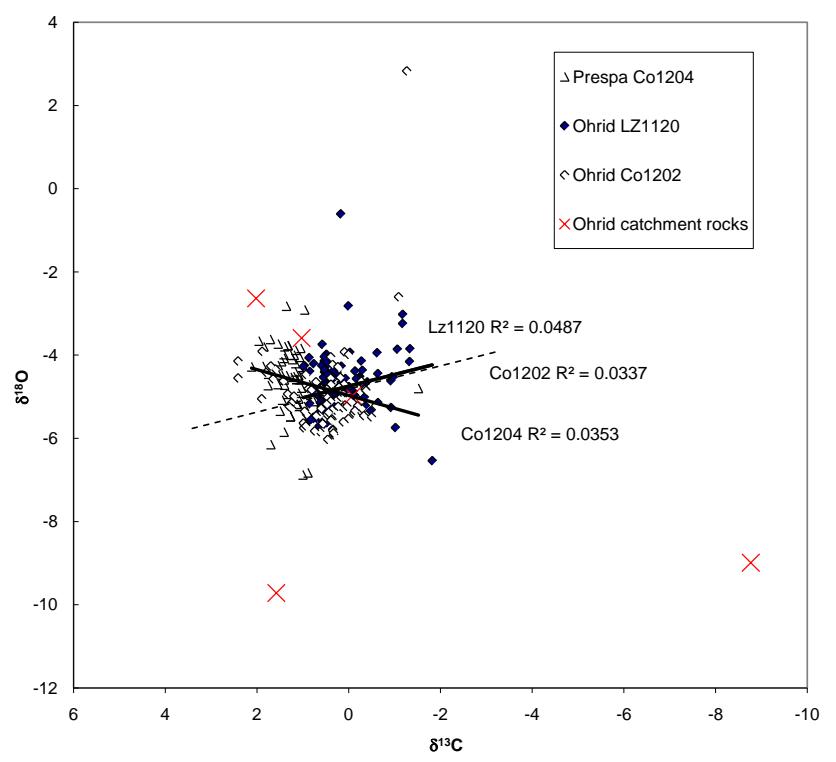

Fig. 6. $\delta^{18} \mathrm{O}$ vs. $\delta^{13} \mathrm{C}$ diagram of authigenic calcite (from Lakes Ohrid and Prespa) and samples of the carbonate catchment rocks surrounding Lake Ohrid. The low isotope values of some of the catchment rocks suggest that they have been post depositionally altered. There are no obvious mixing trends between the isotope composition of the authigenic calcite and the carbonate catchment rocks.

In addition, XRD analysis through the cores show that the carbonate in both lakes is calcite (with dolomite, if present at all, below the limit of detection of XRD), and we know that at least in part the catchment rocks are dolomitized (Dumurdzanov and Ivanovski, 1977) so if there was any significant clastic input we would expect to see some dolomite even if in low concentrations. Within the Holocene all three cores show a broadly similar pattern in $\delta^{18} \mathrm{O}_{\text {calcite }}$ with the early-middle Holocene characterised by the lower values followed (from ca. $6 \mathrm{ka}$ ) by a general trend toward higher $\delta^{18} \mathrm{O}$ (Fig. 7). However, some differences can be highlighted. In Lake Prespa during the early Holocene there is a progressive decrease in $\delta^{18} \mathrm{O}_{\text {calcite }}$ (from ca. 9.4 to $6.4 \mathrm{ka}$, interpreted as being wetter) while Co1202 and Lz1120 show stable values around $-5.5 \%$ outil ca. $5.5 \mathrm{ka}$. The other noticeable difference is the amount of high frequency variation in Prespa compared to Ohrid (i.e. the former record is more spiky than Lz1120 and Co1202). All three lake cores have $\delta^{18} \mathrm{O}_{\text {calcite }}$ ranges that are similar between $-7 \%$ to $-3 \%$, which is surprising given the difference in water volumes $\left(3.6 \mathrm{~km}^{3}\right.$ and $\left.55.4 \mathrm{~km}^{3}\right)$ and residence times $(11$ and $70 \mathrm{yr}$ ) for Lake Prespa and Lake Ohrid respectively. However, Prespa does show that there was increased summer wetness in the early Holocene as Prespa is more sensitive to dry conditions during summer (which causes the greatest effective evaporation, and $\mathrm{I}>\mathrm{E}$ ), this is not recorded in Lake Ohrid probably because of the difference in water volume (see also Wagner et al.,

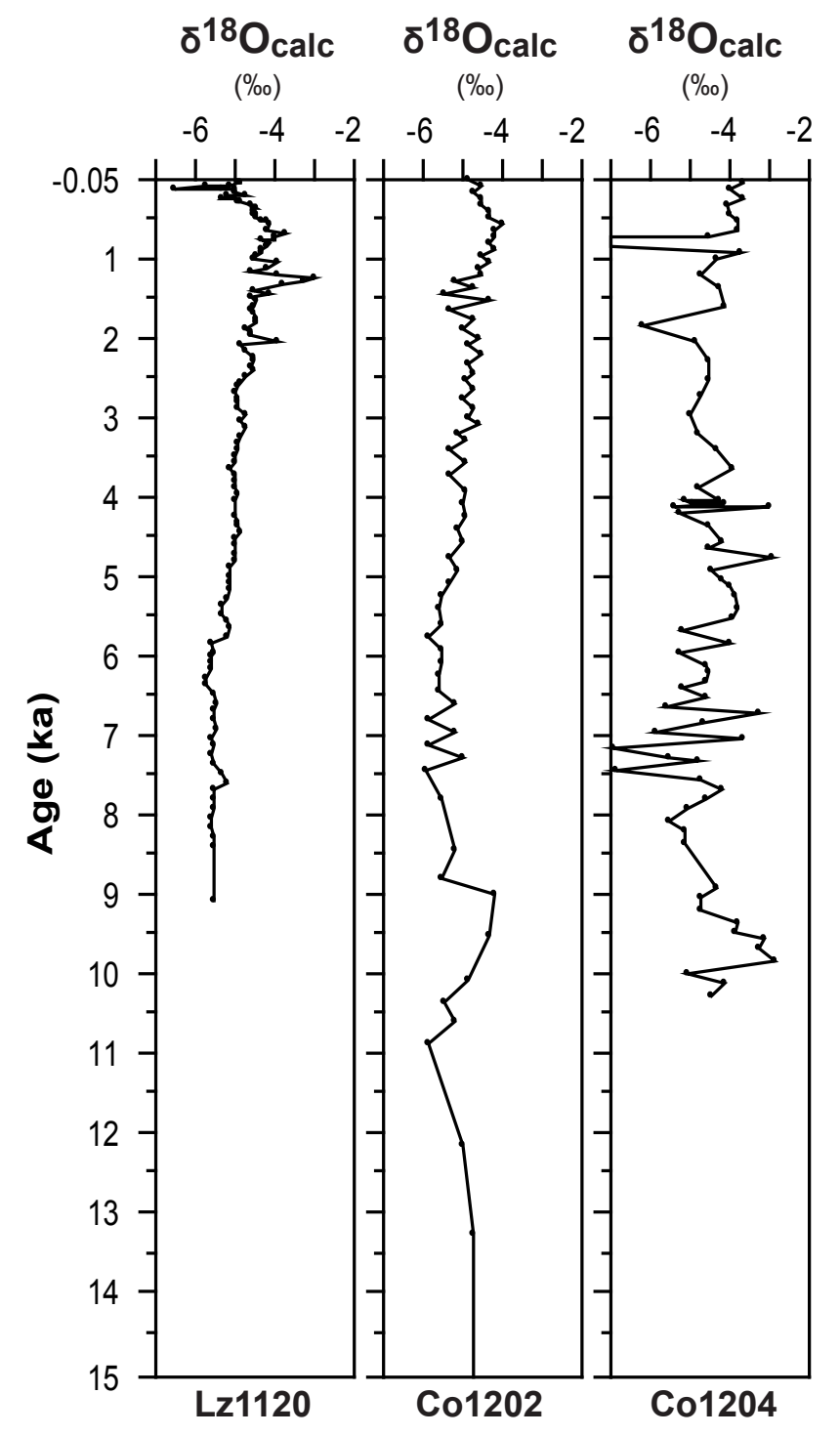

Fig. 7. Comparison of $\delta^{18} \mathrm{O}$ of authigenic calcite in cores Lz1120, Co1202 (Lake Ohrid) and Co1204 (Prespa).

2010). The stability of the Lake Ohrid record suggests that the lake must have retained a substantial body of water during the glacial. The presence of lower $\delta^{18} \mathrm{O}_{\text {calcite }}$ values during the early-middle Holocene is a general feature observed in eastern and central Mediterranean lakes (Roberts et al., 2008; Develle et al., 2010) and speleothem calcite (e.g. BarMatthews et al., 2000; Zanchetta et al., 2007b). This has been interpreted in different ways and has been attributed to increasing the amount of precipitation related to an increase in winter precipitation of Atlantic origin or a significant (especially for eastern Mediterranean) freshening of surface marine water of the eastern Mediterranean at that time (e.g., Kolodny et al., 2005; Develle et al., 2010). The fact that Prespa records the lowest $\delta^{18} \mathrm{O}_{\text {calcite }}$ values at ca. 7.4-7.1 ka may indicate that at this time summer conditions were not 
dry enough to reduce the effect of winter rainfall recharge, whereas in Ohrid the waters were damped by the longer residence time.

It is interesting to focus on core Co1202 (Fig. 4), which better preserves the Late Glacial and Holocene transition. In this core at ca. $15 \mathrm{ka}$ (Fig. 4) the gradual increase in calcite and organic matter content (suggesting increased productivity) is associated with abundant ice rafted debris indicating the persistence of cold winters (with partial ice cover of the lake) but higher spring-summer temperatures, probably at the onset of the warmer climate conditions in the Mediterranean during the Bölling/Alleröd interstadial (Vogel et al., 2010b and references therein). In Co1202 the Younger Dryas is thought to be marked by a fine sand layer, $\mathrm{Cr} / \mathrm{Ti}$ and $\mathrm{Zr} / \mathrm{Ti}$ maxima around $11.8 \mathrm{ka}$, possibly a result of stronger winds and enhanced erosion due to the dry soils and reduction in vegetation (Vogel et al., 2010b). In many Mediterranean lake records the Younger Dryas is marked by a significant increase in the $\delta^{18} \mathrm{O}_{\text {calcite }}$ values (Roberts et al., 2008), the low carbonate content and the low isotope resolution in this interval cannot confirm this signal in Lake Ohrid even if at ca. $11 \mathrm{ka}$ the values are low compared to the immediately preceding Late Glacial.

The trend towards higher $\delta^{18} \mathrm{O}_{\text {calcite }}$ in all three cores through the Holocene suggests progressively drier conditions (and probably lake level drop), perhaps with a sudden reversal in the last few hundred years as $\delta^{18} \mathrm{O}_{\text {calcite }}$ declines to some of the lowest values $(-6.6 \%)$ in the most recent sediments of Lz1120. The trend towards higher $\delta^{18} \mathrm{O}_{\text {calcite }}$ is a feature of many Mediterranean isotopic records both in lakes (e.g. Roberts et al., 2008; Develle et al., 2010) and in speleothems (e.g., Zanchetta et al., 2007b; Bar-Mattews et al., 2000; Verheyden et al., 2008), possibly related to progressive reduction in moisture advection from the Atlantic linked to a reduction in summer insolation, which is also produced by a decrease in monsoon activity on tropical Africa and progressive aridification of the Sahara (e.g. Gasse, 2000; deMenocal et al., 2000). Isotopically this can also be related to progressive increase in isotopic composition in the Mediterranean Sea (Emeis et al., 2000) and the related effect on its moisture contribution to rainfall. However, other records (TIC from Prespa, Wagner et al., 2010) and pollen (Fouache et al., 2010) show reversals in this trend to short wet phases that we don't see in the isotope records. In the modern lakes, assuming peak precipitation of authigenic calcite occurs during the warmer summer months when mean monthly temperatures are high (summer temperatures between 2001 and 2004 were between +20 and $+22^{\circ} \mathrm{C}$, Matzinger et al., 2007), calcite precipitating in Lake Ohrid with mean lakewater value of $-4 \%$ will have a $\delta^{18} \mathrm{O}_{\text {calcite }}$ of between $-5.4 \%$ o and $-5.0 \%$, i.e. an oxygen isotope composition not too dissimilar to the uppermost sediments from Lz1120 (-6.6\%o). This suggests that the current Lake Ohrid is fresher than at any other time (including the late glacial period) although Lake Prespa, with its potential of recording much higher fre- quency variation, does show a fresher period around 7-8 ka. This freshening trend is contrary to what we know about recent aridity in the Mediterranean region, and is potentially driven by anthropogenic change. Roman and recent forest clearance (Wagner et al., 2009), as well as the River Sateska diversion into Lake Ohrid in 1962, means that input has increased leading to an apparent freshening (and decrease in $\left.\delta^{18} \mathrm{O}\right)$.

Between MIS6 and 5 in Co1202, $\delta^{18} \mathrm{O}_{\text {calcite }}$ values vary between $-6 \%$ and $-4 \%$, similar to the range of values seen in the Holocene part of this core. The $\delta^{18} \mathrm{O}_{\text {calcite }}$ values in MIS6 to MIS 5 transition gradually decrease up to ca. $118 \mathrm{ka}$; a profound increase is recorded at ca. $110-115 \mathrm{ka}$, which is lagged by a decrease in $\mathrm{CaCO}_{3}$ content. The first minimum in $\delta^{18} \mathrm{O}_{\text {calcite }}$ correspond to a minimum in $\delta^{13} \mathrm{C}_{\text {calcite }}$ (see later), suggesting a wetter phase (e.g. see discussion also in Lézine et al., 2010). The $\delta^{18} \mathrm{O}_{\text {calcite }}$ increase of ca. $2 \%$ at ca. $110-115 \mathrm{ka}$ is reasonably correlated (within the age errors of the two records) with the cooling phase correlated to Melisey I stadial in core JO2004 in the southern part of the lake (Lézine et al., 2010). A further lowering of $\delta^{18} \mathrm{O}_{\text {calcite }}$ between 107 to $102 \mathrm{ka}$ correlates with part of St. Germain I interstadial as described by Lézine et al. (2010). The progressive $\delta^{18} \mathrm{O}_{\text {calcite }}$ increase up to the hiatus can be viewed as the progressive climatic deterioration described by Lézine et al. (2010) and associated with Melisey II stadial. If this latter interpretation is correct then the Melisey II cooling phase could be related to a protracted aridity phase associated with significant lake level lowering producing the hiatus identified both in core JO2004 (Lézine et al., 2010) and core Co1202 (Vogel et al., 2010a; 2010b; Wagner et al., 2010) and observed in seismic surveys from the northeastern part of the lake (Lindhorst et al., 2010).

\subsection{Carbon isotope composition of bulk calcite}

Lakes that are sensitive to moisture balance (I/E) often have some hydrological closure and precipitate carbonates which have high $\delta^{13} \mathrm{C}_{\text {calcite }}$ (significantly above groundwater bicarbonate levels with $\delta^{13} \mathrm{C}$ ca. $-15 \%$ o to $-10 \%$, Andrews et al., 1993). These lakes also tend to have a covariant relationship between $\delta^{13} \mathrm{C}_{\text {calcite }}$ and $\delta^{18} \mathrm{O}_{\text {calcite }}$ (Talbot, 1990; Leng and Marshall, 2004). High $\delta^{13} \mathrm{C}_{\text {calcite }}$ values reflect different degrees of equilibration of the bicarbonate with atmospheric $\mathrm{CO}_{2}$, while high $\delta^{18} \mathrm{O}_{\text {calcite }}$ is due to preferential evaporative loss of the ${ }^{16} \mathrm{O}$ (leading to high $\delta^{18} \mathrm{O}_{\text {calcite }}$ ) (Talbot, 1990). Experimental data show that isotopic equilibrium with atmospheric $\mathrm{CO}_{2}$ will result in lake water $\delta^{13} \mathrm{C}$ having values between +1 to $+3 \%$ o (Usdowski and Hoefs, 1990), values similar to those from Lake Prespa and Ohrid. Viewed on its own the $\delta^{13} \mathrm{C}_{\text {calcite }}$ data from the lakes appear similar to other large closed basin lakes (i.e. both enriched: e.g. Bosumtwi, Talbot and Kelts, 1986; Malawi, Ricketts and Johnson, 1996; and Turkana, Ricketts and Anderson, 1998), however the critical difference is that the 
Balkan lakes do not show co-variation between $\delta^{13} \mathrm{C}_{\text {calcite }}$ and $\delta^{18} \mathrm{O}_{\text {calcite }}$ (Fig. 6). Roberts et al. (2008) show a summary table of $\delta^{13} \mathrm{C}_{\text {calcite }} \mathrm{v} \delta^{18} \mathrm{O}_{\text {calcite }}$ data from a variety of open and closed lakes across the Mediterranean. They show that the simple $\delta^{13} \mathrm{C}_{\text {calcite }}$ vs. $\delta^{18} \mathrm{O}_{\text {calcite }}$ co-varying relationship of carbonates formed in hydrologically closed lakes first described by Talbot (1990) is not consistent. For example, Tigalmamine (Atlas Mountains, Morocco, e.g. Lamb et al., 1995) shows a significant correlation coefficient of 0.82 , even though the lake is a freshwater, open system, with modern $\delta^{18} \mathrm{O}_{\text {lakewater }}$ of $<-7.5 \%$ (Roberts et al., 2008). The amount of $\delta^{13} \mathrm{C}_{\text {calcite }}$ vs. $\delta^{18} \mathrm{O}_{\text {calcite }}$ co-variation is not simply a function of the amount of closure or residence time and suggests for the Mediterranean at least that this relationship is rather unreliable as a measure of hydrological balance.

Since $\delta^{13} \mathrm{C}_{\text {calcite }}$ is independent of $\delta^{18} \mathrm{O}_{\text {calcite, }}$, we must consider other sources and processes which control the $\delta^{13} \mathrm{C}$ composition of the bicarbonate (which supplies the carbon for the calcite) in the lake. Given that this is a karst region we know that the major source of inorganic carbon will be from dissolution of the old carbonate catchment rocks via springs and rivers entering the lakes, photosynthesis/respiration of aquatic plants within the lake, and $\mathrm{CO}_{2}$ exchange between the atmosphere and lake water. We have not measured the $\delta^{13} \mathrm{C}$ of bicarbonate, but analysis of four out of five geological units in the catchment provide mean $\delta^{13} \mathrm{C}$ values of $+1 \%$ (with one low value of $-8.8 \%$ o which is probably a recent flowstone), and given the $\delta^{13} \mathrm{C}_{\text {calcite }}$ range through the cores $\left(-2\right.$ to $+2 \%$ o), $\delta^{13} \mathrm{C}_{\text {bicarbonate }}$ is likely to be high. In addition, $\delta^{13} \mathrm{C}$ values of bicarbonate in lakes on limestone catchments tend to be high in both bicarbonate content and have enriched isotope values within the range of the aquifer rocks. Moreover, in evaporating lakes, exchange with atmospheric $\mathrm{CO}_{2}$ tends also towards high $\delta^{13} \mathrm{C}_{\text {bicarbonate val- }}$ ues (Andrews et al., 1993). The lakewater bicarbonate pool can also be subsequently changed by biological productivity within the lake, mainly by preferential take up of ${ }^{12} \mathrm{C}$ by aquatic plants during photosynthesis. During periods of enhanced productivity, or in lakes with a large biomass, the carbon pool in the water becomes depleted in ${ }^{12} \mathrm{C}$ and consequently has a higher $\delta^{13} \mathrm{C}_{\text {bicarbonate (assuming sedimentation }}$ of organic matter and not recycling). However if this were the case we would expect variation in $\delta^{13} \mathrm{C}_{\text {calcite }}$ concomitant with high calcite and TOC content as well as $\delta^{13} \mathrm{C}_{\text {org }}$ (as organic matter uses the same $\mathrm{C}$ pool as inorganic carbonate), suggesting that all three processes probably occur in the lakes. There are only a couple of processes that will reduce the $\delta^{13} \mathrm{C}$ of the bicarbonate pool in karstic region lakes, namely oxidation of organic matter within the lake (either allochthonous or allogenic) or input of biogenic (soil) derived $\mathrm{CO}_{2}$ via the karst water. We only see one phase of reduced $\delta^{13} \mathrm{C}_{\text {calcite, }}$, and it is seen more clearly in Lz1120 around 2$3 \mathrm{ka}$, but also as spikes in Co1202 and Co1204, these are not synchronous events but this is likely to reflect the problems with dating. These depletion events coincide with low cal- cite and low TOC (in Lz1120 and Co1202) which might be explained by anthropogenic impacts such as forest clearance bringing greater sediments into the lake diluting the calcite and TOC content. These sediments will carry organic matter from soils and will be readily oxidised. However, this interpretation is not supported by $\mathrm{C} / \mathrm{N}$ data which tends to decrease (in Co1202 and Lz1120), although the difficulty in accurately measuring $\mathrm{N}$ content of these low organic matter sediments $(<1 \%)$ could be leading to an analytical artefact.

In the older part of Co1202 (end of MIS 6 and during MIS 5) there is more variation in $\delta^{13} \mathrm{C}_{\text {calcite, }}$, and a strong covariation between $\delta^{13} \mathrm{C}_{\text {calcite }}$ and $\delta^{13} \mathrm{C}_{\mathrm{org}}$, suggesting a common carbon source. The decline in $\delta^{13} \mathrm{C}_{\text {calcite }}$ and $\delta^{13} \mathrm{C}_{\text {org at }}$ around $120-115 \mathrm{ka}$ is almost certainly due to oxidation of organic matter and it is interesting that this occurs when TOC $(120 \mathrm{ka})$ and $\delta^{18} \mathrm{O}_{\text {calcite }}(118 \mathrm{ka})$ are both slightly lower, but when calcite production was at a high (120 ka) and declining (after $115 \mathrm{ka}$ ). This could be interpreted as more freshwater flux (lower $\delta^{18} \mathrm{O}_{\text {calcite }}$ and declining calcite) and organic matter being oxidised (low TOC and $\delta^{13} \mathrm{C}_{\text {org }}$ ) in Lake Ohrid at this time. Decreasing $\delta^{13} \mathrm{C}_{\text {calcite }}$ in ostracod calcite during this interglacial was also described by Lézine et al. (2010) who suggested that this was driven by increasing soil productivity, which they correlated with increasing arboreal pollen content.

\subsection{Carbon isotope composition of organic matter}

Organic matter within lake sediments can provide information on the palaeoenvironment of a lake and its catchment. Lacustrine organic matter comes predominantly from plant materials and to a lesser extent organisms that live in and around the lake. The concentration of total organic carbon (\%TOC) represents the amount of organic matter preserved after sedimentation, and so depends both on the initial production and the degree of degradation (Meyers and Teranes, 2001). In all three cores there is a noticeable difference between TOC between glacial (no calcite) to interglacial (high calcite) periods (Figs. 3, 4, 5). Lake Prespa preserves significantly more TOC (and less calcite) than Lake Ohrid. Wagner et al. (2010) suggest higher productivity and/or decrease in decomposition of the organic matter possibly as a result of differences in catchment and hydrology (Prespa is mainly fed by river runoff draining the eastern granitoid part of the catchment) and due to the fact that the lake is much shallower meaning that higher water temperatures, more efficient nutrient recycling and enhanced summer productivity.

The amount of sedimentary organic matter that originates from aquatic and terrestrial plants can be sometimes distinguished by $\mathrm{C} / \mathrm{N}$ ratios (\% organic TOC versus $\%$ total $\mathrm{N}$ ) and to a lesser extent by $\delta^{13} \mathrm{C}_{\text {org. }}$. Organic nitrogen occurs preferentially in proteins and nucleic acids which are relatively abundant in lower plants such as aquatic phytoplankton (Talbot and Johannessen, 1992; Meyers and Lallier-Vergès, 1999). Organic material derived solely from 
lacustrine phytoplankton therefore has a characteristically low $\mathrm{C} / \mathrm{N}$ ratio, typically $<10$. The $\mathrm{C} / \mathrm{N}$ ratios from Lake Prespa are quite variable, especially in the glacial, but all ratios are $<13$, and mostly less than 9. In Ohrid the ratios fluctuate within a similar range (4-12), suggesting that the bulk of the organic matter is mainly autochthonous, although the very low values also suggest some selective decomposition. Assuming that the $\delta^{13} \mathrm{C}_{\text {org }}$ signal is derived from a relatively pure algal material then the carbon isotope signal should act as a tracer for past changes in the aquatic carbon cycle assuming limited post depositional change. Lacustrine algae utilise dissolved $\mathrm{HCO}_{3}^{-}$in hard water lakes so variations in the isotope composition of the dissolved $\mathrm{HCO}_{3}^{-}$and changes in $\delta^{13} \mathrm{C}$ related to productivity and nutrient supply are both possible. Already described above we suggest that the main source of carbon ions to the lakes is the dissolved bicarbonate from the limestone catchment rocks, and this will also be utilised by the plants growing in the lakes. Phytoplankton for example, preferentially utilise ${ }^{12} \mathrm{C}$ to produce organic matter that averages $20 \%$ ower than the $\delta^{13} \mathrm{C}$ of the bicarbonate ion (Leng et al., 2005). Therefore, changes in the bicarbonate pool can have significant effects on the $\delta^{13} \mathrm{C}$ of bulk organic material. In the Holocene $\delta^{13} \mathrm{C}_{\text {calcite }}$ is rather complacent apart from a period 2-3 ka which we describe above. In the Pleistocene, changes in $\delta^{13} \mathrm{C}_{\text {calcite }}$ are mimicked in $\delta^{13} \mathrm{C}_{\text {org }}$ in core Co1202, although this is more complex because a similar variation is also seen in $\mathrm{C} / \mathrm{N}$, suggesting that vegetation change may also occur (although the variation is still $<12$ which does not indicate significant allogenic input) suggesting that this variation is more a function of changes in internal carbon cycling. The decline in $\delta^{13} \mathrm{C}_{\text {org }}$ in the early MIS5, and also seen in the early Holocene of lake Prespa, maybe a function of progressive development of soils (Wagner et al., 2009; Lézine et al., 2010). After the Last Glacial many northern European lakes formed and most of their carbon was in the form of $\mathrm{HCO}_{3}^{-}$from glacial clay which generally has high $\delta^{13} \mathrm{C}$ (Hammarlund et al., 1997) mainly due to the fact that the glacial clay often incorporates geological marine carbonate (most of the catchment rock samples from around Lake Ohrid also have high $\delta^{13} \mathrm{C}$ ). Incorporation of this isotopically enriched carbon (from dissolution of glacial clay carbon) into phytoplankton leads to the production of organic matter with higher $\delta^{13} \mathrm{C}_{\text {org }}$. As soils developed there is a source of ${ }^{13} \mathrm{C}$-poor $\mathrm{CO}_{2}$ to the groundwater recharging the lakes and leads to decreasing $\delta^{13} \mathrm{C}$ in the carbonates (e.g., Hammarlund et al., 1997). In the Pleistocene (Co1202) we see a $\delta^{13} \mathrm{C}_{\text {org }}$ decrease at the beginning of the interglacial and then $\delta^{13} \mathrm{C}_{\text {org }}$ increases. Increasing $\delta^{13} \mathrm{C}_{\text {org }}$ may also be a function of biological productivity, mainly by preferential uptake of ${ }^{12} \mathrm{C}$ by aquatic plants during photosynthesis. During periods of enhanced productivity, or in lakes with a large biomass, the carbon pool in the water becomes enriched in ${ }^{13} \mathrm{C}$ (if organic matter is sedimented rather than recycled). If productivity has driven some of the $\delta^{13} \mathrm{C}_{\mathrm{org}}$ variation we might expect synchronous changes with the amount of calcite and organic matter.

Interestingly $\delta^{13} \mathrm{C}_{\text {org }}$ during the glacial period in Lake Prespa is higher than in the Holocene and corresponds to low TOC, this might suggest a reduction of oxidation of $\delta^{13} \mathrm{C}_{\text {org }}$ depleted organic matter (although productivity must have been low) suggesting that dissolved $\mathrm{CO}_{2}$ originating from mineralization of organic matter was further reduced as would be any contribution of soil- $\mathrm{CO}_{2}$ leached from the catchment. This latter interpretation is in agreement with a general deterioration of climate conditions during the glacial (MIS 4, 3,2) characterised by prevailing cold and arid condition producing steppe biome, as indicated by pollen data for the region (e.g. Allen et al., 1999, 2000; Wagner et al., 2009; Lézine et al., 2010). The Prespa $\delta^{13} \mathrm{C}_{\text {org }}$ record also shows several significant "spikes" in the glacial data to values as high as $-20 \%$, it is difficult to explain these ${ }^{13} \mathrm{C}$-enriched values but one possibility is that they represent phases of higher primary productivity in a lake with low $\mathrm{CO}_{2}$ allowing the lake to become an active sink of atmospheric $\mathrm{CO}_{2}$ (Herchzeg and Fairbanks, 1987), possibly triggered by short periods of climate improvement. Whatever the cause of these differences between Ohrid and Prespa $\delta^{13} \mathrm{C}_{\text {org }}$ it is probably in part due to the much shallower lakewater depth of Lake Prespa and its more efficient organic matter recycling.

\section{Conclusions}

The three lake sediment records discussed here (Lz1120 and Co1202 from Ohrid, and Co1204 from Lake Prespa) overlap only for the last ca. $40 \mathrm{ka}$, Co1202 is the longest record and contains the MIS $6 / 5$ transition. The sedimentary characteristics of both lakes differ significantly between glacial and interglacial phases. At the end of MIS 6 lake level was low (high $\delta^{18} \mathrm{O}_{\text {calcite }}$ ) and, although productivity was increasing (increasing calcite content), the carbon supply was mainly from inorganic catchment rock sources (high $\delta^{13} \mathrm{C}_{\text {carb }}$ ). During the last interglacial, calcite and TOC production and preservation increased, progressively lower $\delta^{18} \mathrm{O}_{\text {calcite }}$ suggest increase in humidity and perhaps higher lake levels, but around $115 \mathrm{ka}$ there is isotopic evidence of climatic deterioration. The synchronicity of $\delta^{13} \mathrm{C}_{\text {org }}$ vs. $\delta^{13} \mathrm{C}_{\text {carb }}$ suggests a relatively simple within lake carbon cycle being driven by bicarbonate supply and changes in organic matter oxidation. Peak oxidation and supply of isotopically light $\delta^{13} \mathrm{C}_{\text {org }}$ occurred around $117 \mathrm{ka}$, substantially in phase with lower $\delta^{18} \mathrm{O}_{\text {carb}}$, suggesting the wettest phase of the MIS5.

During ca. $80 \mathrm{ka}$ to $11 \mathrm{ka}$ the lake records suggest cold conditions as indicated by negligible calcite precipitation and low organic matter content. In Lake Ohrid $\delta^{13} \mathrm{C}_{\text {org }}$ are complacent, in contrast Lake Prespa shows consistently higher $\delta^{13} \mathrm{C}_{\text {org }}$ suggesting a reduction in oxidation of ${ }^{13} \mathrm{C}$-depleted organic matter in agreement with a general deterioration of climate conditions during the glacial and/or input of more 
soil $\mathrm{CO}_{2}$ to the system. The Prespa $\delta^{13} \mathrm{C}_{\text {org }}$ record shows several significant "spikes" in the glacial period to high values and may represent phases of higher primary productivity in a system with low bicarbonate concentration and therefore where the equilibration with atmospheric $\mathrm{CO}_{2}$ becomes significant.

In Co1202 from $15 \mathrm{ka}$ to the onset of the Holocene, calcite and TOC begin to increase, suggesting lake levels were probably low (high $\delta^{18} \mathrm{O}_{\text {calcite }}$ ). A hiatus marks this period in Lz1120. In Prespa there is no calcite in this period and TOC doesn't start to increase until $10 \mathrm{ka}$. During the Holocene ( $11 \mathrm{ka}$ to present) enhanced productivity is manifested as high calcite and organic matter content. All three cores show an early Holocene characterised by low $\delta^{18} \mathrm{O}_{\text {calcite, }}$, apart from the early Holocene phase in Prespa, where there is a trend towards lowering $\delta^{18} \mathrm{O}_{\text {calcite }}$ up to ca $7.5 \mathrm{ka}$. Presumably, this may represent the phase of higher lake level, at least in Ohrid. The other noticeable difference is the amount of high frequency variation in Prespa compared to Ohrid within the overall drying trend.

The latter half of the Holocene (starting around $6 \mathrm{ka}$ ) is characterised by increasing $\delta^{18} \mathrm{O}_{\text {calcite }}$ values, indicating a progressive aridification, in agreement with many other records in the Mediterranean (e.g., Roberts et al., 2008). However, the upper part of Lz1120 has very low $\delta^{18} \mathrm{O}_{\text {calcite, }}$, which might suggest human activity (e.g. in 1962 the River Sateska was diverted into Lake Ohrid, and forest clearance). Overall, the isotope data presented here confirm that these two big lakes have captured the large scale, low frequency palaeoclimate variation that is evidenced in Mediterranean lakes, although in detail there is much palaeoclimate information that could be gained, especially the small scale, high frequency differences between this region and the Mediterranean if better dating of the most recent sediments were available.

Edited by: T. Wilke

\section{References}

Allen, J. R. M., Brandt, U., Brauer, A., Hubberten, H.-W., Huntley, B., Keller, J., Kraml, M., Mackensen, A., Mingram, J., Negendank, J. F. W., Nowaczyk, N. R., Oberhänsli, H., Watts, W. A., Wulf, S., and Zolitschka, B.: Rapid environmental changes in southern Europe during the last glacial period, Nature, 400, 740743, 1999.

Aliaj, S., Baldassare, G., and Shkupi, D.: Quaternary subsidence zones in Albania: some case studies, B. Eng. Geol. Environ., 59, 313-318, 2001.

Allen, J. R. M., Watts, W. A., and Huntley, B.: Weichselian palynostratigraphy, palaeovegetation and palaeoenvironment; the record form Lago Grande di Monticchio, southern Italy, Quatern. Int., 73/74, 91-110, 2000.

Amataj, S., Anovsky, T., Benischke, R., Eftimi, R., Gourcy, L. L., Kola, L., Leontiadis, I., Micevsky, E., Stamos, A., and Zoto, J.: Tracer methods used to verify the hypothesis of Cviji about the underground connection between Prespa and Ohrid Lake, Environ. Geol., 51, 749-753, 2007.

Andrews, J. E., Riding, R., and Dennis, P. F.: Stable isotope compositions of recent freshwater cyanobacterial carbonates from the British Isles: local and regional environmental controls, Sedimentology, 40, 303-314, 1993.

Anovski, T., Naumovski, J., Kacurkov, D., and Kirkov, P.: A study of the origin of waters of St. Naum Springs, Lake Ohrid, Fisika, 12, 76-86, 1980 (in Macedonian).

Anovski, T., Andonovski, B., and Mineva, B.: Study of the hydrological relationship between lakes Ohrid and Prespa, Proceedings of an IAEA international symposium, IAEA-SM-Vienna 11-15 March 1991, 319, 62, 1991.

Anovski, T. (ed.): Progress in the Study of Prespa Lake using Nuclear and Related Techniques, Project Report, IAEA Regional Project RER/8/008, ISBN 9989-650-21-7, Skopje, Macedonia, 2001 .

Bar-Matthews, M., Ayalon, A., and Kaufman, A.: Timing and hydrological conditions of Sapropel events in the Eastern Mediterranean as evident from speleothems, Soreq cave, Israel, Chem. Geol., 169, 145-156, 2000.

Belmecheri, S., Namiotko, T., Robert, C., von Grafenstein, U., and Danielopold, D. L.: Climate controlled ostracod preservation in Lake Ohridnext term (Albania, Macedonia), Palaeogeogr. Palaeocl., 277(3-4), 236-245, 2009.

Bolle, H.J.: Mediterranean Climate. Variability and Trends, Springer, Berlin, 2003.

Danzeglocke, U., Jöris, O., and Weninger, B.: CalPal-2007 ${ }^{\text {online }}$, online available at: http://www.calpal-online.de, accessed 200911-21, 2009.

deMenocall, P., Ortiz, J., Guilderson, T., Adkins, J., Sarthein, M., Baker, L., and Yarusinsky, M.: Abrupt onset and termination of the African Humid Period: rapid climate responses to gradual insolation forcing, Quaternary Sci. Rev., 19, 347-361, 2000.

Develle, A. L., Herreros, J., Vidal, L., Sursock, A., and Gasse, F.: Controlling factors on paleo-lake oxygen isotope record (Yammouneh, Lebanon) since the Last Glacial Maximum, Quaternary Sci. Rev., 29, 865-886, 2010.

Dotsika, E., Lykoudis, S., and Poutoukis, D.: Spatial distribution of the isotopic composition of precipitation and spring water in Greece, Global Planet. Change., 71(3-4), 141-149, doi:10.1016/j.gloplacha.2009.10.007, 2010.

Dumurdzanov, N. and Ivanovski, T.: Geological Map of the Socialist Federal Republic of Yugoslavia, Sheet Ohrid, Geological Survey Belgrad, 1977.

Emeis, K-C., Struck, U., Schulz, H.-M., Rosenberg, R., Bernasconi, S., Erlekeuser, H., Sakamoto, T., and Martinez-Ruiz, F.: Temperature and salinity variations of Mediterranean Sea surface waters over the last 16,000 years from records of planktonic stable oxygen isotopes and alkenone unsaturation ratios, Palaeogeogr. Palaeocl., 158, 259-280, 2000.

Eftimi, R. and Zoto, J.: Isotope study of the connection of Ohrid and Prespa lakes, International Symposium "Towards Integrated Conservation and Sustainable Development of Transboundary Macro and Micro Prespa Lakes”, Korcha, Albania, 1997.

Fouache, E., Desruelles, S., Magny, M., Bordon, A., Oberweiler, C., Coussot, C., Touchais, G., Lera, P., Lézine, A-M., Fadin, L and Roger, R.: Palaeogeographical reconstructions of Lake Maliq (Korça Basin, Albania) between 14,000 BP and 2000 BP, 
J. Archaeol. Sci., 37, 525-535, 2010.

Frogley, M. R., Griffiths, H. I., and Heaton, T. H. E.: Historical biogeography and Late Quaternary environmental change of Lake Pamvotis, Ioannina (north-western Greece): evidence from ostracods, J. Biogeogr., 28, 745-756, 2001.

Gasse, F.: Hydrological changes in the African tropics since the Last Glacial Maximum, Quaternary Sci. Rev., 19, 189-211, 2000.

Gat, J. R., Klein, B., Kushnir, Y., Roether, W. Wernli, H., Yam, R., and Shemesh, A.: Isotope composition of air moisture over the Mediterranean Sea: an index of the air-sea interaction, Tellus, 55B, 959-965, 2003.

Hadzisce, S. D.: Das Mixophänomen im Ohridsee im Laufe der Jahre 1941/42-1964/65, Verh. Internat. Verein. Limnol., 16, 134-138, 1966.

Hammarlund, D., Aravena, R., Barnekow, L., Buchardt, B., and Possnert, G.: Multi-component carbon isotope evidence of early Holocene environmental change and carbon-flow pathways from a hard-water lake in northern Sweden, J. Paleolimnol., 18, 219233, 1997.

Herchzeg, A. L. and Fairbanks, R. G.: Anomalous carbon isotope fractionation between atmospheric $\mathrm{CO} 2$ and dissolved inorganic carbon induced by intense photosynthesis, Geochim. Cosmochim. Ac., 51, 895-899, 1987.

Hollis, G. E. and Stevenson, A. C.: The physical basis of the Lake Mikri Prespa systems: geology, climate, hydrology and water quality, Hydrobiologia, 351, 1-19, 1997.

Kolodny, Y., Stein, M., and Machlus, M.: Sea-rain-lake relation in the Last Glacial East Mediterranean revealed by $\delta^{18} \mathrm{O}-\delta^{13} \mathrm{C}$ in Lake Lisan aragonites, Geochim. Cosmochim. Ac., 69, 40454060, 2005.

Lamb, H. F., Gasse, F., Benkaddour, A., el-Hamouti, N., van der Kaars, S., Perkins, W. T., Pearce, N. J., and Roberts, N.: Relation between century-scale Holocene arid intervals in tropical and temperate zones, Nature, 373, 134-137, 1995.

Leng, M. J., Lamb A. L., Heaton T. H. E., Marshall J. D., Wolfe B. B., Jones M. D, Holmes J. A., and Arrowsmith C.: Isotopes in lake sediments, in: Isotopes in Palaeoenvironmental Research, edited by: Leng M. J., Springer, Dordrecht, The Netherlands, 148-176, 2005.

Leng, M. J., Jones, M. D., Frogley, M. R., Eastwood, W. J., Kendrick, C. P., and Roberts, C. N.: Detrital carbonate influences on bulk oxygen and carbon isotope composition of lacustrine sediments from the Mediterranean, Global Planet. Change, 71, 175-182, 2010.

Leng, M. J. and Marshall, J. D.: Palaeoclimate interpretation of stable isotope data from lake sediment archives, Quaternary Sci. Rev., 23, 811-831, 2004.

Lézine, A.-M., von Grafenstein, U., Andersen, N., Belmecheri, S., Bordon, A., Caron, B., Cazet, J. P., Erlenkeuser, H., Fouache, E., Grenier, C., Huntsman-Mapila, P., Hureau-Mazaudier, D., Manelli, D., Mazaud, A., Robert, C., Sulpizio, R., Tiercelin, J. J., Zanchetta, G., and Zeqollari, Z.: Lake Ohrid, Albania, provides an exceptional multi-proxy record of environmental changes during the last glacial-interglacial cycle, Palaeogeogr. Palaeocl., 287, 116-127, 2010.

Lindhorst, K., Vogel, H., Krastel, S., Wagner, B., Hilgers, A., Zander, A., Schwenk, T., Wessels, M., and Daut, G.: Stratigraphic analysis of lake level fluctuations in Lake Ohrid: an integration of high resolution hydro-acoustic data and sediment cores, Biogeosciences Discuss., 7, 3651-3689, doi:10.5194/bgd-7-3651-2010, 2010.

Lionello, P., Malanotte-Rizzoli, P., and Boscolo, R.: Mediterranean Climate Variability, 4, Elsevier, The Netherlands, 2006.

Matter, M., Anselmetti, F. S., Jordanoska, B., Wagner, B., Wessels, M., and Wüest, A.: Carbonate sedimentation and effects of eutrophication observed at the Kalita subaquatic springs in Lake Ohrid (Macedonia), Biogeosciences Discuss., 7, 47154747, doi:10.5194/bgd-7-4715-2010, 2010.

Matzinger, A., Jordanoski, M., Veljanoska-Sarafiloska, E., Sturm, M., Müller, B., and Wüest, A.: Is Lake Prespa jeopardizing the ecosystem of ancient Lake Ohrid?, Hydrobiologia, 553, 89-109, 2006a.

Matzinger, A., Schmid, M., Veljanoska-Sarafiloska, E., Patceva, S., Guseska, D., Wagner, B., Müller, B., Sturm, M., and Wüest, A.: Eutrophication of ancient Lake Ohrid: global warming amplifies detrimental effects of increased nutrient inputs, Limnol Oceanogr., 52, 338-353, 2007.

Matzinger, A., Spirkovski, Z., Patceva, S., and Wüest, A.: Sensitivity of ancient Lake Ohrid to local anthropogenic impacts and global warming, J. Great Lakes Res., 32, 158-179, 2006 b.

Meyers, P. A., and Lallier-Vergès, E.: Lacustrine sedimentary organic matter records of Late Quaternary paleoclimates, J. Paleolimnol., 21, 345-372, 1999.

Meyers, P. A. \& Teranes, J. L.: Sediment organic matter. Tracking environmental change using lake sediments, in: Volume 2: Physical and Geochemical Methods, edited by Last, W. M. and Smol, J. P., Dordrecht, The Netherlands, Kluwer Academic Publishers, 2001.

Popovska, C. and Bonacci, O.: Basic data on the hydrology of Lakes Ohrid and Prespa, Hydrol. Process., 21, 658-664, 2007.

Ricketts, R. D. and Anderson, R. F.: A direct comparison between the historical record of lake level and the $\delta^{18} \mathrm{O}$ signal in carbonate sediments from Lake Turkana, Kenya, Limnol. Oceanogr., 43, 811-822, 1998.

Ricketts, R. D. and Johnson, T. C.: Early Holocene changes in lake level and productivity in Lake Malawi as interpreted from oxygen and carbon isotopic measurements from authigenic carbonates, in: The limnology, climatology and palaeoclimatology of the East Africa lakes, edited by: Johnson, T. C. and Odada, E. O., Gordon and Breach, Amsterdam, 1996.

Roberts, N., Jones, M. D., Benkaddour, A., Eastwood, W. J., Filippi, M. L., Frogley, M. R., Lamb, H. F., Leng, M. J., Reed, J. M., Stein, M., Stevens, L., Valero-Garcés, B., and Zanchetta, G.: Stable Isotope records of Late Quaternary climate and hydrology from Mediterranean lakes: the ISOMED synthesis, Quaternary Sci. Rev., 27, 2426-2441, 2008.

Stankovic, S.: The Balkan Lake Ohrid and its living world, Monographiae Biologicae IX, Dr. W. Junk, Den Haag, The Netherlands, 1960.

Sulpizio, R., Zanchetta, G., D’Orazio, M., Vogel, H., and Wagner, B.: Tephrostratigraphy and tephrochronology of lakes Ohrid and Prespa, Balkans, Biogeosciences Discuss., 7, 3931-3967, doi:10.5194/bgd-7-3931-2010, 2010.

Talbot, M. R.: A review of paleohydrological interpretation of carbon and oxygen isotopic rations in primary lacustrine carbonates, Chem. Geol., 80, 261-279, 1990.

Talbot, M. and Johannessen, T.: A high resolution palaeoclimatic 
record for the last 27,500 years in tropical West Africa from the carbon and nitrogen isotopic composition of lacustrine organic matter, Earth Planet. Sc. Lett., 110, 1, 23-37, 1992.

Talbot, M. R. and Kelts, K.: Primary and diagenetic carbonates in the anoxic sediments of Lake Bosumtwi, Ghana, Geology, 14, 912-916, 1986.

Usdowski, E. and Hoefs, J.: Kinetic C-13 C-12 and O-18 O-16 effects upon dissolution and outgassing of $\mathrm{CO}_{2}$ in the system $\mathrm{CO}_{2}-\mathrm{H}_{2} \mathrm{O}$, Chem. Geol., 80, 109-118, 1990.

Verheyden, S., Nader, F. H., Cheng, H. J., Edwards, L. R., and Swennen, R.: Paleoclimate reconstruction in the Levant region from geochemistry of a Holocene stalagmite from jeita cave, Lebanon, Quaternary Res., 70, 368-381, 2008.

Vogel, H., Wagner, B., Zanchetta, G., Sulpizio, R., and Rosén, P.: A paleoclimate record with tephrochronological age control for the last glacial-interglacial cycle from Lake Ohrid, Albania and Macedonia, J. Paleolimnol., 44, 295-310, 2010b.

Vogel, H., Zanchetta, G., Sulpizio, R., Wagner, B., and Nowaczyk, N.: A tephrostratigraphic record for the last glacial interglacial cycle from Lake Ohrid, Albania and Macedonia, J. Quaternary Sci., 25, 320-338, 2010a.

Wagner, B., Lotter, A. F., Nowaczyk, N., Reed, J. M., Schwalb, A., Sulpizio, R., Valsecchi, V., Wessels, M., and Zanchetta, G.: A 40,000-year record of environmental change from ancient Lake Ohrid (Albania and Macedonia), J. Paleolimnol., 41, 407-430, 2009.
Wagner, B., Sulpizio, R., Zanchetta, G., Wulf, S., Wessels, M., and Daut, G.: The last 40 ka tephrostratigraphic record of Lake Ohrid, Albania and Macedonia: a very distal archive for ash dispersal from Italian volcanoes, J. Volcanol. Geoth. Res., 177, 7180, 2008.

Wagner, B., Vogel, H., Zanchetta, G., and Sulpizio, R.: Environmental changes on the Balkans recorded in the sediments from lakes Prespa and Ohrid, Biogeosciences Discuss., 7, 3365-3392, doi:10.5194/bgd-7-3365-2010, 2010.

Watzin, M. C., Puka, V., and Naumoski, T. B.: Lake Ohrid and its watershed, state of the environment report, Lake Ohrid Conservation Project, Tirana, Albania and Ohrid, Macedonia, 2002.

Wetzel, R. G.: Limnology - Lake and River Ecosystems, 3rd ed., Academic Press, San Diego, 2001.

Zanchetta, G., Bonadonna, F. P., and Leone, G.: A 37-Meter Record of Paleoclimatological Events from Stable Isotope Data on Continental Molluscs in Valle di Castiglione, Near Rome, Italy, Quaternary Res., 52, 293-299, 1999.

Zanchetta, G., Borghini, A., Fallick, A.E., Bonadonna, F.P., and Leone, G.: Late Quaternary palaeohydrology of Lake Pergusa (Sicily, southern Italy) as inferred by stable isotopes of lacustrine carbonates, J. Paleolimnol., 38, 227-239, 2007a.

Zanchetta, G., Drysdale, R. N., Hellstrom, J. C., Fallick, A. E., Isola, I., Gagan, M. K., and Pareschi, M. T.: Enhanced rainfall in the Western Mediterranean during deposition of sapropel S1: stalagmite evidence from Corchia cave (Central Italy), Quaternary Sci. Rev., 26, 279-286, 2007b. 